\title{
内蒙古索伦山蛇绿岩带早二叠世放射虫动物群的发现 及其地质意义
}

李钢柱 ${ }^{1^{*}}$, 王玉净 ${ }^{2}$, 李成元 ${ }^{1}$, 白宇明 ${ }^{1,3}$, 薛建平 ${ }^{1,3}$, 赵广明 ${ }^{1}$, 薄海军 ${ }^{1}$, 梁月升 ${ }^{1}$, 刘伟 ${ }^{1}$

1. 武警黄金第二支队, 呼和浩特 010010 ;

2. 中国科学院南京地质古生物研究所, 南京 210008 ;

3. 中国地质大学地球科学与资源学院, 北京 100083

* 联系人, E-mail: ligzh08@163.com

2016-06-16 收稿, 2016-11-07 修回, 2016-11-07 接受, 2017-01-06 网络版发表

中国地质调查局地质调查项目(12120113071800)资助

摘要位于中蒙边境地区的索伦山蛇绿岩带, 是古生代存在于西伯利亚板块与华北板块之间的古亚洲洋闭合之 后形成的索伦山缝合带的重要组成部分. 索伦山蛇绿岩的研究, 对认识古亚洲洋演化具有重要意义, 但其时代一 直是学术界争论的焦点问题之一。本次工作采集索伦山蛇绿岩带硅质岩样品，对其进行了放射虫化石的分选与鉴 定. 在内蒙古乌拉特中旗北部靠近中蒙边境线的索伦山蛇绿岩带硅质岩中发现早二叠世放射虫动物群, 包括 5 个属 6 个种, 其中有4个未定种和1个新种: Pseudoalbaillella bulbosa, Ps. solonensis Wang sp. nov., Stigmosphaerostylus sp., Ruzhencevispongus sp., Cenosphaera sp., Latentifistula sp.等. Pseudoalbaillella bulbosa这个种在日本、泰国、智利、 北美西海岸和中国华南等地发现在晚石炭世一早二叠世硅质岩相地层中, 在中国作为早二叠世早期的一个带种, 成为广海相硅质岩相区石炭系与二叠系分界的标志. 这套放射虫硅质岩属索伦山蛇绿岩的组成部分, 该动物群的 发现为索伦山蛇绿岩形成时间持续到早二叠世提供了关键证据. 这些新证据证实了古亚洲洋在早二叠世时仍存 在, 古亚洲洋通过俯冲消减最终闭合应是在早二叠世之后.

关键词放射虫, 早二叠世, 蛇绿岩, 索伦山, 古亚洲洋

索伦山蛇绿岩作为消失在华北板块与西伯利亚 板块之间的古亚洲洋存在的重要证据, 记录了古亚 洲洋复杂的构造演化历史 ${ }^{[1 \sim 11]}$, 受到了国内外学者的 广泛关注. 索伦山蛇绿岩的研究, 对认识古亚洲洋演 化、恢复洋陆格局、了解华北板块与西伯利亚板块拼 合时间与过程等, 具有重要的科学意义.

目前科学界普遍认为索伦山缝合带是华北板块 与西伯利亚板块最终对接的位置 ${ }^{[1,2,4,9 ~ 12]}$. 前人对保 存在其中的大洋岩石圈残片一一索伦山蛇绿岩做了 较多研究, 但是多侧重于对蛇绿岩中镁铁质-超镁铁
质岩组成部分的同位素测年和岩石地球化学研究, 对其共生的深海远洋沉积盖层(放射虫硅质岩)中的 放射虫动物群组成及其时代研究还很薄弱, 对索伦 山蛇绿岩的形成时代还存在不同看法. 因而, 对上述 两大板块之间古亚洲洋的闭合时间及构造演化的认 识尚存在分歧.

对于索伦山蛇绿岩的形成时代主要有以下几种 观点：(1) 形成于早石炭世 ${ }^{[13,14]}$; (2) 晚泥盆世-早石 炭世或更早 ${ }^{[15]}$ 、早泥盆世或之前 ${ }^{[16,17]}$; (3) 张旗等 人 $^{[18]}$ 认为索伦山蛇绿岩时代是志留纪-泥盆纪; (4)

引用格式: 李钢柱, 王玉净, 李成元, 等. 内蒙古索伦山蛇绿岩带早二叠世放射虫动物群的发现及其地质意义. 科学通报, 2017, 62: 400-406 Li G Z, Wang Y J, Li C Y, et al. Discovery of Early Permian radiolarian fauna in the Solon Obo ophiolite belt, Inner Mongolia and its geological significance (in Chinese). Chin Sci Bull, 2017, 62: 400-406, doi: 10.1360/N972016-00703 
陈志勇 ${ }^{[19]}$ 获得索伦山蛇绿岩东延部分巴彦敖包蛇绿 岩中橄榄辉长岩TIMS锆石 U-Pb年龄为 $385.6 \pm 1.7 \mathrm{Ma}$, 为早泥盆世; (5) 陶继雄等人 ${ }^{[20]}$ 根据索伦山蛇绿岩橄 榄辉长岩的 $\mathrm{U}-\mathrm{Pb}$ 年龄 $433.6 \pm 3.6 \mathrm{Ma}$, 认为该套蛇绿岩 形成时代为早志留世晚期; (6) Miao等人 ${ }^{[6]}$ 获得索伦 山地区堆晶辉长岩 SHRIMP锆石 U-Pb年龄为 $279 \pm 10$ $\mathrm{Ma}$, Jian等人 ${ }^{[21]}$ 获得索伦山蛇绿岩中辉长岩SHRIMP 锆石 $\mathrm{U}-\mathrm{Pb}$ 年龄为 $296.6 \pm 1.7 \sim 291.8 \pm 2.3 \mathrm{Ma}$, 认为索伦 山蛇绿岩形成于早二叠世. 王惠等人 ${ }^{[22]}$ 根据索伦山 蛇绿岩带东延部分巴彦敖包地区发现的早二叠世晚 期-中二叠世早期的放射虫化石, 认为索伦山蛇绿混 杂岩带混杂堆积的时间为中二叠世早期.

本文的研究是在武警黄金第二支队开展的内蒙 古索伦山地区六幅 $1: 50000$ 区域地质矿产调查工作的 基础上, 对索伦山蛇绿岩的物质组成、产出状态和相 互接触关系等进行了系统调查研究, 采集了索伦山 蛇绿岩带硅质岩样品, 对其进行放射虫化石的分选
与鉴定, 以确定蛇绿岩的形成时代, 进而探讨古亚洲 洋形成和演化的时限.

\section{1 地质概况}

索伦山蛇绿岩带位于内蒙古乌拉特中旗北部中 蒙边境线附近，呈近东西向分布，西起索伦敖包西哈 布塔盖，向东经索伦敖包、乌珠尔少布特，到满都拉 地区哈尔陶勒盖，向北延人蒙古国，境内出露宽 $1 \sim 6$ $\mathrm{km}$, 长约 $100 \mathrm{~km}$, 为区域上中亚造山带中一条重要 的蛇绿构造混杂岩带. 索伦山蛇绿岩组成以超镁铁 质岩为主, 辉长岩、辉绿岩、枕状玄武岩和放射虫硅 质岩等均有出露, 岩块之间及与围岩均为构造接触. 索伦山蛇绿岩的基质为一套强片理化砂泥质和硅泥 质等细碎屑岩(图1).

超镁铁质岩主要包括方辉橄榄岩、二辉橄榄岩和 纯橄榄岩等, 均遭受强烈蛇纹石化; 辉长岩可能代表 堆晶岩部分; 玄武岩见枕状构造, 应为蛇绿岩顶部部
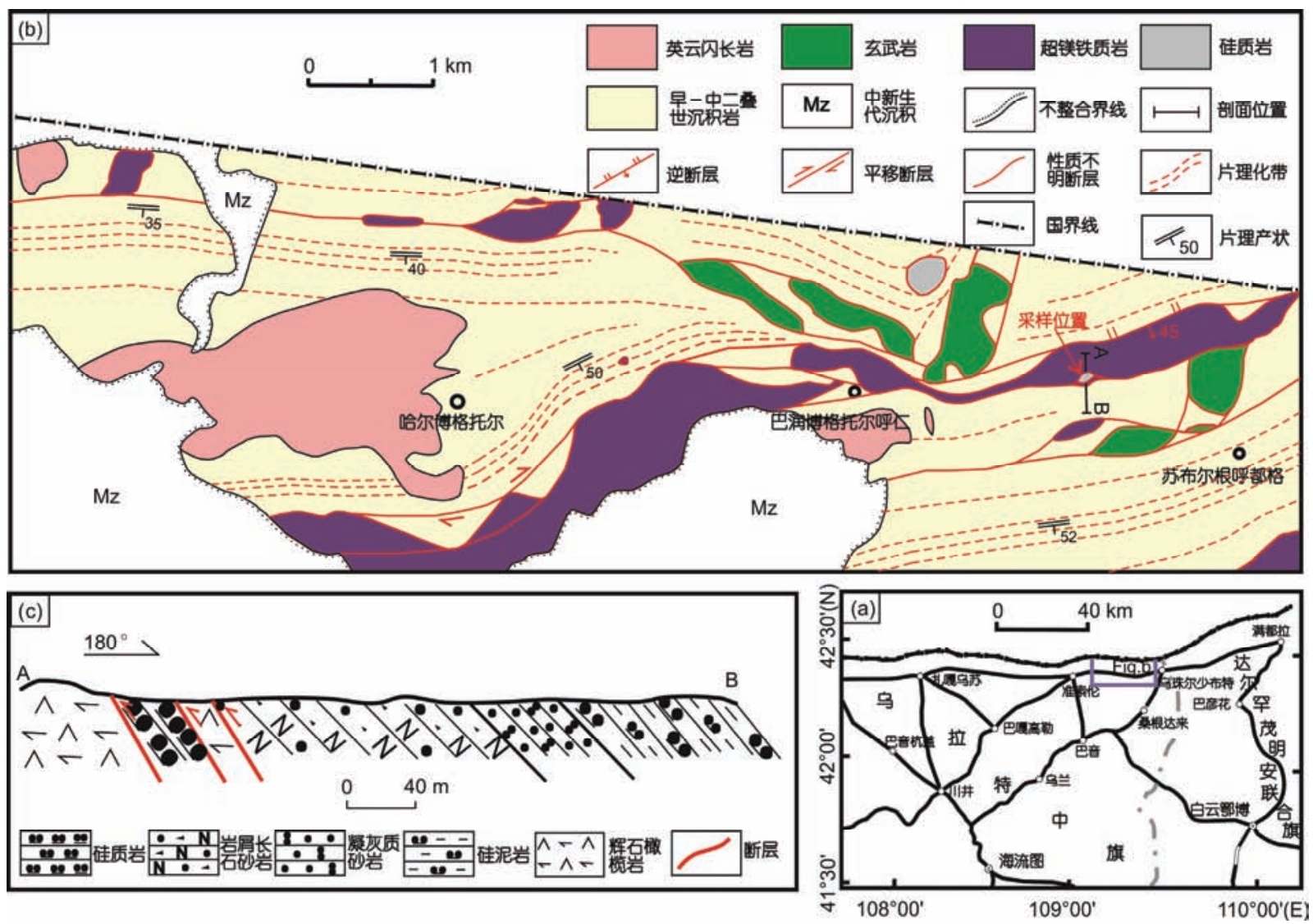

图 1 内蒙古乌拉特中旗索伦山地区蛇绿岩分布区地质简图与采样位置

Figure 1 Simplified geological map showing the distribution of ophiolite in the Solon Obo area of Urad Middle Banner, Inner Mongolia, with sample location 
分; 含放射虫硅质岩代表蛇绿岩深海沉积部分.

\section{2 放射虫化石特征及时代}

含放射虫硅质岩样品采自准索伦北东约 $25 \mathrm{~km}$ 处 苏布尔根呼都格地区, 样品编号PM55b2, 采样位置 坐标为 $42.23^{\circ} \mathrm{N}, 109.23^{\circ} \mathrm{E}$, 硅质岩颜色为深灰色, 呈小 岩块产出, 与超镁铁质岩呈断层接触(图1(b), (c)和2). 本次填图工作中在索伦山蛇绿岩带中发现的硅质岩 有紫红色、灰绿色、青灰色、深灰色和灰黑色等5类, 硅质岩岩石薄片中多处见到放射虫化石, 但大多保 存不好, 仅在上述采样点硅质岩中发现保存较完好 的个体(图2(b)). 经中国科学院南京地质古生物研究 所王玉净研究员鉴定, 这个放射虫动物群包括 5 个属 6个种, 其中有 4 个未定种和 1 个新种: Pseudoalbaillella bulbosa, Ps. solonensis Wang sp. nov., Stigmosphaerostylus sp., Ruzhencevispongus sp., Cenosphaera sp., Latentifistula sp. 等 (图 3). 新种 Pseudoalbaillella solonensis(索伦假阿尔拜虫) 与Ps. u-forma不同的主 要特征是假腹节末端有孔. Pseudoalbaillella bulbosa 这个种在日本被Ishiga认为是晚石炭世-早二叠世 的 ${ }^{[23,24]}$, 而在泰国、智利、北美西海岸和中国华南都 发现在早二叠世硅质岩相地层中, 因此, 这个种已成 为早二叠世早期的一个带种 ${ }^{[25 ~ 27]}$, 并成为广海相硅 质岩相区石炭系和二叠系分界的标志.

该放射虫动物群以假阿尔拜虫类和内射虫类最 为丰富, 约各占动物群的 $45 \%$. 假阿尔拜虫类多由顶 锥和假胸节组成, 完整个体较少. 内射虫类个体较 多, 刺细长, 多数折断不完整. 隐管虫类、空球虫类 和鲁仁采夫海绵虫类数量较少. 整个放射虫化石约 占岩石的 $50 \%$ 以上, 属于真正的放射虫岩(radiolite), 是蛇绿岩的组成部分, 因此, 放射虫化石所确定的时
代可以代表蛇绿岩形成的时代. 这套放射虫硅质岩 属索伦山蛇绿岩的组成部分, 该动物群的发现为索 伦山蛇绿岩形成时间持续到早二叠世提供了关键 证据.

\section{3 讨论}

1977 1980年内蒙古第一区域地质调查队在索伦 山地区开展 “1:20万桑根达来等4幅区域地质调查” 时, 认为索伦山地区出露的超基性岩为侵人成因, 根 据灰岩透镜体中化石等证据将索伦山蛇绿混杂岩归 为中石炭统本巴图组和侵人其中的超基性岩, 并初 步认为可能存在混杂堆积. 朱绅玉等人 ${ }^{[28]}$ 提出索伦 山超基性岩为蛇绿岩, 之后许多研究者从板块构造 角度对该蛇绿岩带做了大量工作, 对该套蛇绿岩的 岩石类型、分布、产出状态等作了报道 ${ }^{[9,15,17,20,29 \sim 31]}$, 但是对其详细的物质组成、构造特征等还缺少系统的 调查研究, 对其形成时代还存在较大争议. 索伦山缝 合带向东延伸位置, 也存在与二连-贺根山缝合带相 连 $^{[1,15,16,32 ~ 35]}$, 与西拉木伦 (林西)缝合带相连 ${ }^{[3,4,7,36 \sim 38]}$ 等不同认识.

本次 1:50000地质填图从原 1:20万区调划分的 “本巴图组+超基性岩”中解体出方辉橄榄岩、二辉橄 榄岩、纯橄榄岩、辉长岩、辉绿岩、玄武岩和放射虫 硅质岩等蛇绿岩组合, 和早-中二叠世砂泥质、硅泥 质基质(图1(b)), 本巴图组仅在区内南部出露, 与蛇 绿混杂岩呈断层接触. 本次获得的早二叠世放射虫 化石与区内测得的蛇绿岩中辉长岩 $280.7 \pm 5.3 \mathrm{Ma}$ 的 锆石 $\mathrm{U}-\mathrm{Pb}$ 年龄(另文发表)吻合较好, 二者相互印证, 表明索伦山蛇绿岩形成时代持续到早二叠世.

王惠等人 ${ }^{[22]}$ 在索伦山蛇绿岩东延部分满都拉地 区巴彦敖包硅质岩中发现早二叠世晚期-中二叠世早
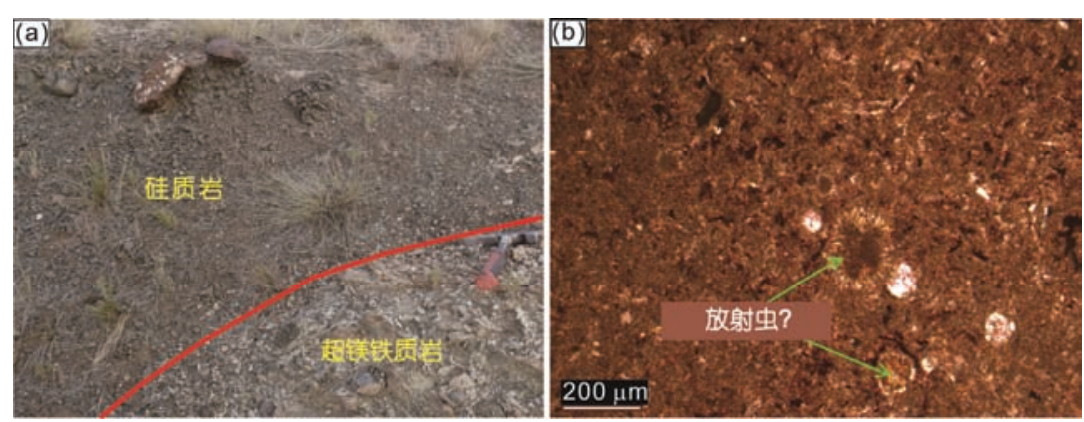

图 2 索伦山蛇绿岩放射虫硅质岩野外地质特征(a)及显微照片(b)

Figure 2 Geological features (a) and photomicrograph (b) of the radiolarian cherts of Solon Obo ophiolite belt 

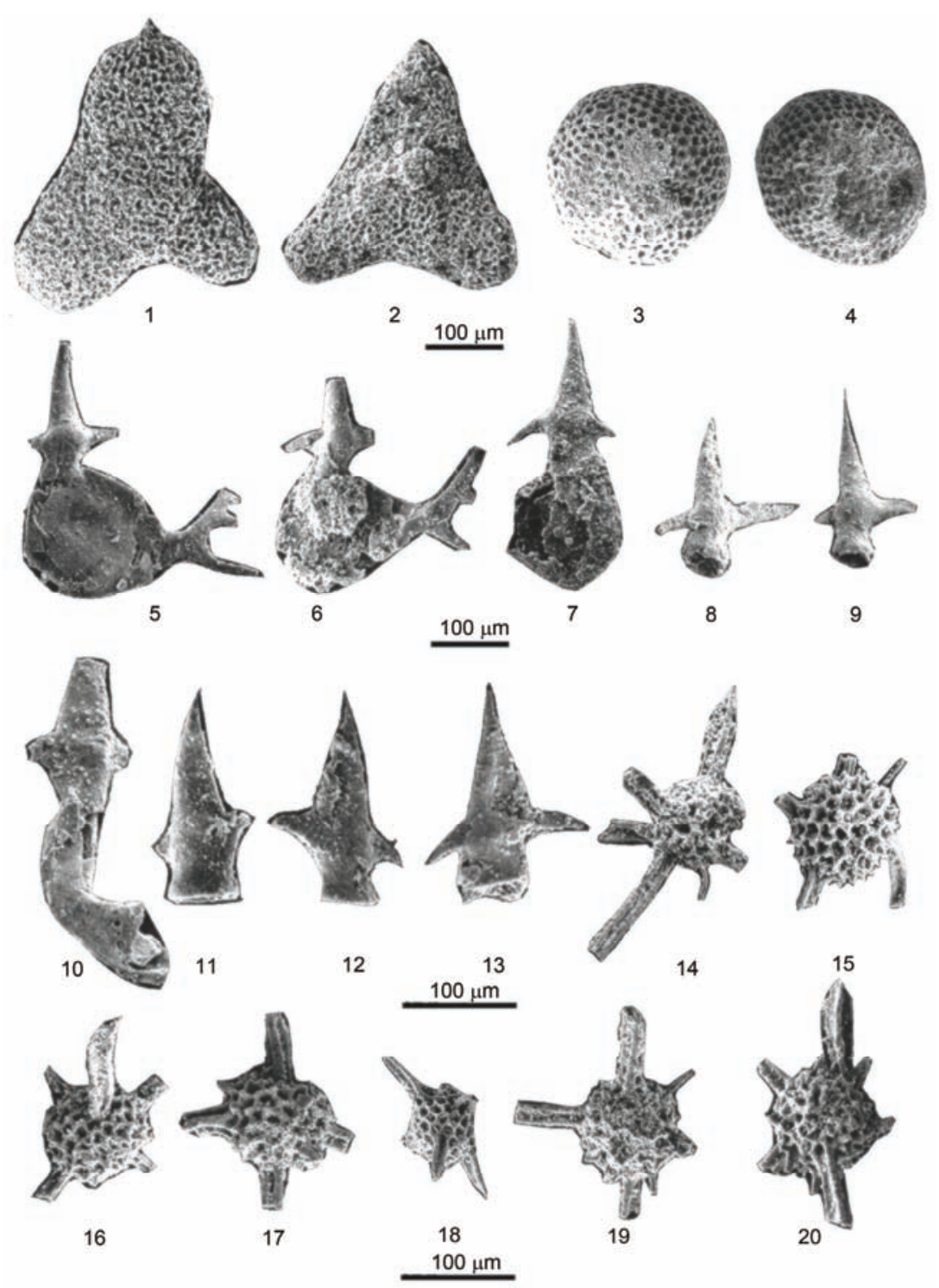

图 3 内蒙古乌拉特中旗索伦山地区索伦山蛇绿岩硅质岩中放射虫化石. 1, 2, Ruzhencevispongus sp. 鲁任采夫海绵虫(未定种); 3, 4, Cenosphaera sp. 空球虫(未定种); 5 9, Pseudoalbaillella bulbosa球茎形假阿尔拜虫; 10 13, Pseudoalbaillella solonensis Wang sp. nov. 索伦假阿尔拜 虫(新种); 14 20, Stigmosphaerostylus sp. 斑点球桩虫(未定种)

Figure 3 The radiolarian fossils in the cherts of Solon Obo ophiolite belt of Urad Middle Banner, Inner Mongolia. 1, 2, Ruzhencevispongus sp.; 3, 4, Cenosphaera sp.; 5-9, Pseudoalbaillella bulbosa; 10-13, Pseudoalbaillella solonensis Wang sp. nov.; 14-20, Stigmosphaerostylus sp.

期的放射虫化石，尚庆华 ${ }^{[39]}$ 在满都拉地区混杂岩带 沉积岩块中发现中二叠世放射虫化石, Miao等人 ${ }^{[6]}$ 报 道了索伦山地区堆晶辉长岩的SHRIMP锆石U-Pb年 龄为 $279 \pm 10 \mathrm{Ma}, J i a n$ 等人 ${ }^{[21]}$ 获得索伦山蛇绿岩中辉 长岩 SHRIMP 锆石 U-Pb 年龄为 $296.6 \pm 1.7 \sim 291.8 \pm 2.3$ $\mathrm{Ma}$, 反映了索伦山-满都拉一带在早-中二叠世时仍 处于洋盆形成与发展阶段.

王玉净等人 ${ }^{[36]}$ 在内蒙古西拉木伦河北部杏树洼 蛇绿岩带硅质岩中发现了Ormistonella robusta De
Wever et Caridroit, Pseudotormentus kamigoriensis De Wever et Caridroit, Ishigaum trifistis De Wever et Caridroit等中二叠世中晚期的放射虫化石，王荃等 人 $^{[13]}$ 在贺根山蛇绿岩基性熔岩所夹的硅质岩中发现 放射虫Entactinia sp., Tetrentactinia sp., Cenellipsis sp. 等, 时代为晚泥盆世. 之前一些学者 ${ }^{[32 ~ 35]}$ 认为古亚洲 洋最终闭合位置在索伦山-贺根山一带, 但随着研究 的不断深人，特别是近几年大量同位素年龄等证据的 获得, 目前地学界多数学者认为古亚洲洋最终闭合位 
置应在索伦山-林西 ${ }^{[6,11]}$ 或索伦山-西拉木伦一带 ${ }^{[5,36,40]}$, 闭合时间在晚二叠世-早三叠世 ${ }^{[4,5,40,41]}$ 或晚二叠世-中 三叠世 ${ }^{[11]}$. 很显然, 本次新获得的放射虫化石证据支 持古亚洲洋在晚二叠世-早中三叠世闭合的观点.

总之, 本次工作在索伦山蛇绿岩带硅质岩中新 发现早二叠世放射虫化石, 证实了在内蒙古索伦山 地区, 古亚洲洋在早二叠世时仍存在, 其最终闭合的 时间应是在早二叠世之后.

\section{4 结论}

综上所述, 可得出以下几点认识:
(1) 索伦山蛇绿岩带硅质岩中新发现放射虫动 物群, 包括5个属6个种: Pseudoalbaillella bulbosa, Ps. solonensis Wang sp. nov., Stigmosphaerostylus sp., Ruzhencevispongus sp., Cenosphaera sp., Latentifistula $\mathrm{sp}$. 等, 其时代为早二叠世. 这套放射虫硅质岩属索 伦山蛇绿岩的组成部分, 该动物群的发现为索伦山 蛇绿岩形成时间持续到早二叠世提供了关键证据.

(2) 索伦山蛇绿岩带硅质岩中早二叠世放射虫 化石的发现, 证实索伦山地区古亚洲洋在早二叠世 时仍存在, 古亚洲洋通过俯冲消减最终闭合的时间 应是在早二叠世之后.

野外调查采样工作得到武警黄金第二支队首长和战友大力协助，内蒙古地质勘查院段秀和高工在野外工作中提 供了宝贵的建议, 国土资源部成都地质矿产研究所潘桂棠研究员亲临野外指导, 审稿人提出了非常宝贵的意见 建议, 在此表示衰心的感谢.

\section{参考文献}

1 Sengor A M C, Natal'in B A, Burtman V S. Evolution of the Altaid tectonic collage and Paleozoic crustal growth in Eurasia. Nature, 1993, 364: 299-307

2 Sengor A M C, Natal'in B A. Paleotectonics of Asia: Fragments of a synthensis. In: Yin A, Harrison M, eds. The Tectonic Evolution of Asia. Cambridge: Cambridge University Press, 1996. 486-640

3 Dobretsov N L, Berzin N A, Buslov M M. Opening and tectonic evolution of the Paleo-Asian Ocean. Int Geol Rev, 1995, 37: 335-360

4 Li J Y. Permian geodynamic setting of Northeast China and adjacent regions: Closure of the Paleo-Asian Ocean and subduction of the Paleo-Pacific Plate. J Asian Earth Sci, 2006, 26: 207-224

5 Li J Y, Zhang J, Yang T N, et al. Crustal tectonic division and evolution of the southern part of the North Asian orogenic region and its adjacent areas (in Chinese). J Jilin Univ, 2009, 39: 584-605 [李锦轶，张进，杨天南，等. 北亚造山区南部及其毗邻地区地壳构造分区 与构造演化. 吉林大学学报, 2009, 39: 584-605]

6 Miao L, Zhang F, Fan W, et al. Phanerozoic evolution of the Inner Mongolia-Daxinganling orogenic belt in North China: Constraints from geochronology of ophiolites and associated formations. Geol Soc Lond Spec Publ, 2007, 280: 223-237

7 Jian P, Liu D Y, Kroner A, et al. Time scale of an early to middle-Paleozoic orogenic cycle of the long-lived Central Asian Orogenic Belt, Inner Mongolia of China: Implications for continental growth. Lithos, 2008, 101: 233-259

8 Zhang S H, Gao R, Li H Y, et al. Crustal structures revealed from a deep seismic reflection profile across the Solonker suture zone of the Central Asian Orogenic Belt, northern China: An integrated interpretation. Tectonophysics, 2014, 612-613: 26-39

9 Xiao W J, Windley B F, Hao J, et al. Accretion leading to collision and the Permian Solonker suture, Inner Mongolia, China: Termination of the Central Asian orogenic belt. Tectonics, 2003, 22: 1-18

10 Xiao W J, Windley B F, Huang B C, et al. End-Permian to mid-Triassic termination of the accretionary processes of the southern Altaids: Implications for the geodynamic evolution, Phanerozoic continental growth, and metallogeny of Central Asia. Int J Earth Sci, 2009, 98: 1189-1217

11 Xiao W J, Windley B F, Sun S, et al. A tale of amalgamation of three Permo-Triassic collage systems in Central Asia: Oroclines, sutures, and terminal accretion. Annu Rev Earth Planet Sci, 2015, 43: 477-507

12 Windley B F, Alexeiev D, Xiao W J, et al. Tectonic models for accretion of the Central Asian Orogenic belt. J Geol Soc Lond, 2007, 164: 31-47

13 Wang Q, Liu X Y, Li J Y. Plate Tectonic Between Cathyasia and Angara (in Chinese). Beijing: Peking University Press, 1991. 1-151 [王 荃, 刘雪亚, 李锦轶. 中国华夏与安加拉古陆间的板块构造. 北京: 北京大学出版社, 1991. 1-151]

14 Xiao X C, Tang Y Q, Li J Y, et al. On tectonic evolution of the southern margin of the Paleoasian composite megasuture zone (in Chinese). In: Xiao X C, ed. On Tectonic Evolution of the Southern Margin of the Paleoasian Composite Megasuture Zone. Beijing: Beijing Science \& Technology Press, 1991. 1-29 [肖序常, 汤耀庆, 李锦轶, 等. 古中亚复合巨型缝合带南缘构造演化. 见: 肖序常, 编. 古 中亚复合巨型缝合带南缘构造演化. 北京: 北京科学技术出版社, 1991. 1-29]

15 Shao J A. Crust Evolution in the Middle Segment of the Northern Margin of Sino-Korea Plate (in Chinese). Beijing: Peking University Press, 1991. 1-91 [邵济安. 中朝板块北缘中段地壳演化. 北京：北京大学出版社, 1991. 1-91] 
16 Tang K D. Tectonic development of Paleozoic foldbelts at the north margin of the Sino-Korean Craton. Tectonics, 1990, 9: 249-260

17 Tang K D. Structural Evolution and Metallogenic Regularity of Fold Belt in North Side of Sino-Korea Plate (in Chinese). Beijing: Peking University Press, 1992. 69-90 [唐克东. 中朝板块北侧禇皱带构造演化及成矿规律. 北京：北京大学出版社, 1992. 69-90]

18 Zhang Q, Zhou G Q, Wang Y. The distribution of time and space of China ophiolites, and their tectonic setting (in Chinese). Acta Petrol Sin, 2003, 19: 1-8 [张旗, 周国庆, 王焰. 中国蛇绿岩的分布、时代及其形成环境. 岩石学报, 2003, 19: 1-8]

19 Chen Z Y. Tectonic evolution from middle-Proterozoic to Paleozoic in Guyang-Mandula area, Inner Mongolia (in Chinese). Doctor Dissertation. Beijing: China University of Geosciences, 2005. 1-129 [陈志勇. 内蒙古固阳-满都拉地区中元古代-古生代地质构造演化. 博士学位论文. 北京: 中国地质大学, 2005. 1-129]

20 Tao J X, Su M R, Baoyin W, et al. Characteristics and tectonic significance of the Solon mountain ophiolitic mélange in the Mandula area, Darhan Muminggan, Inner Mongolia (in Chinese). Geol Bull Chin, 2004, 23: 1238-1242 [陶继雄，苏茂荣，宝音乌力吉，等. 内蒙古达 尔罕茂明安联合旗满都拉地区索伦山蛇绿混杂岩的特征及构造意义. 地质通报, 2004, 23: 1238-1242]

21 Jian P, Liu D Y, Kroner A, et al. Evolution of a Permian intraoceanic arc-trench system in the Solonker suture zone, China and Mongolia. Lithos, 2010, 118: 169-190

22 Wang H, Wang Y J, Chen Z Y, et al. Discovery of the Permian radiolarians from the Bayanaobao area, Inner Mongolia (in Chinese). J Stratigr, 2005, 29: 368-371 [王惠, 王玉净, 陈志勇, 等. 内蒙古巴彦敖包二叠纪放射虫化石的发现. 地层学杂志, 2005, 29: 368-371]

23 Ishiga H. Late Carboniferous and Permian radiolarian biostratigraphy of Southwest Japan. J Geosci, 1986, 29: 89-100

24 Ishiga H. Paleozoic radiolarians. In: Ichikawa K, Mizutani S, Hara I, et al., eds. Pre-Cretaceous Terranes of Japan. Osaka: Nippon Satsu, 1990. 285-295

25 Wang Y J, Yang Q. Carboniferous-Permian radiolarian biozones of China and their Palaeobiogeographic implication. Acta Micropalaeontol Sin, 2007, 24: 337-345 [王玉净, 杨群. 中国石炭-二叠纪放射虫化石带及古生物地理学意义. 微体古生物学报, 2007, 24: 337-345]

26 Yao A, Kuwahara K. Radiolarian fossils from the Permian-Triassic of China. News Osaka Micropaleontol, 2004, 13: 29-45

27 Mikiko S, Yao A. Lower-Middle Permian radiolarian biostratigraphy in the Qinzhou area, South China. J Geosci, 2006, 49: 31-47

28 Zhu S Y, Li B Y. The ophiolites in Solon Obo area, Inner Mongolia (in Chinese). In: Plate Tectonics Corpus in the North of China (1). Beijing: Chinese Academy of Geological Sciences, 1983. 105-114 [朱绅玉，李宝玉. 内蒙古索伦敖包地区蛇绿岩. 见: 中国北方板块 构造文集(第一集). 北京: 中国地质科学院, 1983.105-114]

29 Liang R X. The features of ophiolites in the gentral sector of Inner Mongolia and its geological significance (in Chinese). Region Geol China, 1994, 1: 37-45 [梁日暄. 内蒙古中段蛇绿岩特征及地质意义. 中国区域地质, 1994, 1: 37-45]

30 Chen B, Ma X H, Liu A K. Zircon U-Pb ages of the Xilinhot metamorphic complex and blueschist, and implication for tectonic evolution of the Solonker suture (in Chinese). Acta Petrol Sin, 2009, 25: 3123-3129 [陈斌，马星华，刘安坤，等. 锡林浩特杂岩和蓝片岩的锆石 $\mathrm{U}-\mathrm{Pb}$ 年代学及其对索仑缝合带演化的意义. 岩石学报, 2009, 25: 3123-3129]

31 Li Y L, Zhou H W, Brouwer F M, et al. Tectonic significance of the Xilin Gol complex, Inner Mongolia, China: Petrological, geochemical, and U-Pb zicon age constraints. J Asian Earth Sci, 2011, 42: 1018-1029

32 Cao C Z. The plate framework of northeastern China (in Chinese). Bull Shenyang Inst Geol Min Res Chin Acad Geol Sci, 1987, 16: 60-67 [曹从周. 中国东北部的板块构造格局. 中国地质科学院沈阳地质矿产研究所文集, 1987, 16: 60-67]

33 Hsu K J, Wang Q, Li L, et al. Geologic evolution of the Neimonides: A working hypothesis. Eclogae Geol Helv, 1991, 84: 1-31

34 Chen B, Jahn B M, Wilde S, et al. Two contrasting Paleozoic magmatic belts in northern Inner Mongolia, China: Petrogenesis and tectonic implications. Tectonophysics, 2000, 328: 157-182

35 Nozaka T, Liu Y. Petrology of the Hegenshan ophiolite and its implication for the tectonic evolution of north China. Earth Planet Sci Lett, 2002, 202: 89-104

36 Wang Y J, Fan Z Y. Discovery of Permian radiolarians in ophiolite belt on northern side of Xar Moron River, Inner Mongolia and its geological significance (in Chinese). Acta Palaeontol Sin, 1997, 36: 58-69 [王玉净, 㚞志勇. 内蒙古西拉木伦河北部蛇绿岩带中二叠纪 放射虫的发现及其地质意义. 古生物学报, 1997, 36: 58-69]

37 Li J Y, Gao L M, Sun G H, et al. Shuangjingzi Middle Triassic syn-collisional crust-derived granite in the east Inner Mongolia and its constraint on the timing of collision between Siberian and Sino-Korean paleo-plate (in Chinese). Acta Petrol Sin, 2007, 23: 565-582 [李 锦轶, 高立明, 孙桂华, 等. 内蒙古东部双井子中三叠世同碰撞壳源花岗岩的确定及其对西伯利亚与中朝古板块碰撞时限的约束. 岩石学报, 2007, 23: 565-582]

38 Jian P, Kroner A, Windley B F, et al. Carboniferous and Cretaceous mafic-ultramafic massifs in Inner Mongolia (China): A SHRIMP zircon and geochemical study of the previously presumed integral "Hegenshan ophiolite". Lithos, 2012, 142-143: 48-66

39 Shang Q H. Occurrences of Permian radiolarians in central and eastern Nei Mongol (Inner Mongolia) and their geological significance to the Northern China Orogen. Chin Sci Bull, 2004, 49: 2613-2619 [尚庆华. 北方造山带内蒙古中、东部地区二叠纪放射虫的发现及意 义. 科学通报, 2004, 49: 2574-2579]

40 Eizenhofer P R, Zhao G C, Zhang J, et al. Final closure of the Paleo-Asian Ocean along Solonker suture zone: Constraints from geochronological and geochemical data of Permian volcanic and sedimentary rocks. Tectonics, 2014, 33: 441-463

41 Zhang S H, Zhao Y, Kroner A, et al. Early Permian plutons from the northern North China Block: Constraints on continental arc evolution and convergent margin magmatism related to the Central Asian Orogenic Belt. Int J Earth Sci, 2009, 98: 1441-1467 


\title{
Discovery of Early Permian radiolarian fauna in the Solon Obo ophiolite belt, Inner Mongolia and its geological significance
}

\author{
LI GangZhu ${ }^{1 *}$, WANG YuJing ${ }^{2}$, LI ChengYuan ${ }^{1}$, BAI YuMing ${ }^{1,3}$, XUE JianPing ${ }^{1,3}$, \\ ZHAO GuangMing ${ }^{1}$, BO HaiJun ${ }^{1}$, LIANG YueSheng ${ }^{1} \&$ LIU Wei $^{1}$ \\ ${ }^{1}$ No. 2 Gold Geological Team of CAPF, Huhhot 010010, China; \\ ${ }^{2}$ Nanjing Institute of Geology and Palaeontology, Chinese Academy of Sciences, Nanjing 210008, China; \\ ${ }^{3}$ School of Earth Sciences and Resources, China University of Geosciences, Beijing 100083, China \\ * Corresponding author, E-mail: ligzh08@163.com
}

The Solon Obo ophiolite belt in Inner Mongolia is located close to the border between China and Mongolia. It is an integral part of the Solon Obo tectonic suture formed by the closure of the Paleo-Asian Ocean between Siberia Craton and North China Craton in the Paleozoic. This ophiolite belt is a rare remnant of the Paleo-Asian Ocean and thus provides important samples for the study of tectonic evolution in the eastern part of the Central Asian Orogenic Belt in North China. The age of the tectonic event of the Solon Obo tectonic suture has been debated for a long time. Some researchers believe that it was from Silurian to Devonian whereas other researchers believe it was from Early Carboniferous to Early Permian. Here we report the first discovery of Early Permian radiolarians in the cherts of the ophiolite belt.

The Solon Obo ophiolite belt is E-W trending, with a total length of $\sim 100 \mathrm{~km}$. It is mainly composed of ultramafic intrusive rocks such as harzburgite, lherzolite, dunite and pyroxenite, and gabbro, diabase, basalts and cherts. On the base of the field geological investigation and 1:10000 structure-lithology mapping in the Solon Obo area, we took cherts samples from the Solon Obo ophiolite belt in the Subuergen Hudag area of northern Urad Middle Banner, Inner Mongolia, and carried out studies including petrologic characteristics of cherts, separation and identification of the radiolarian fossils in cherts. Early Permian radiolarian fauna is first found in the chert of Solon obo ophiolite belt. This fauna is composed of 5 genera and 6 species (including 4 unidentified species and 1 new species), Pseudoalbaillella bulbosa, Ps. solonensis Wang sp. nov., Stigmosphaerostylus sp., Ruzhencevispongus sp., Cenosphaera sp., Latentifistula sp. etc. The new species, Pseudoalbaillella solonensis can be distinguished from Ps. u-forma by its holes in the end of the pseudoabdominal segment. Pseudoalbaillella bulbosa, found in Late Carboniferous-Early Permian cherty strata of Japan, Thailand, Chile, Western Coast of North America and South China is regarded as a zonal species of early Early Permian time in China and has become one mark of the boundary between Carboniferous and Permian cherty strata in open marine facies. This radiolarian fauna is characterized by rich Pseudoalbaillellids and Entactinids which have possessed about $45 \%$ of this fauna respectively. The Pseudoalbaillellids are mostly composed of the apical cones and many pseudothoraxes with smaller entire individuals. The Entactinids are numerous in number and their spines are longer, but incomplete due to break. Other radiolarians, such as Latentifistalids, Cenosphaerids and Ruzhencevispongids are rare. These radiolarian fossils possessing over $50 \%$ in whole rocks are considered as the radiolite which is a component of the ophiolite. Therefore, the time determined by radiolarian fossils may represent forming age of the ophiolites and this set of radiolite is known as a part of the Solon Obo ophiolite belt. The discovery of this radiolarian fauna has provided a key evidence about forming age of the Solon Obo ophiolite lasted until Early Permian.

This new discovery, together with the previously reported zircon U-Pb ages of 279-296 Ma for the associated mafic-ultramafic rocks in the Solon Obo ophiolite belt, confirms that the final closure of the Paleo-Asian Ocean took place no early than Early Permian.

radiolarian, Early Permian eposh, ophiolite, Solon Obo, Paleo-Asian Ocean

doi: 10.1360/N972016-00703 